\title{
Ecotourism in the Tangkoko DuaSudara Nature Reserve: opening Pandora's box?
}

\author{
Margaret F. Kinnaird and Timothy G. O'Brien
}

Indonesia, like many other developing countries, is turning to ecotourism in an attempt to integrate the goals of development and nature conservation. Although ecotourism may be a valuable tool for preservation of biodiversity, it can have long-term negative effects on reserves, wildlife and local communities if improperly managed. In this study the authors evaluated ecotourism in the Tangkoko DuaSudara Nature Reserve, North Sulawesi, by examining trends in visitor numbers, the tourist experience, the distribution of tourist revenues, and tourist impact on the Sulawesi black macaque Macaca nigra and spectral tarsier Tarsier spectrum. The data collected showed that, although tourism is expanding rapidly, local benefits are not being fully realized, the reserve does not generate enough money to implement management, and primate behaviour is being affected. There is urgent need for a change in legal status of the reserve if ecotourism is to be managed. National park status would accommodate ecotourism planning and development, provide for greater participation by the local community, and allow for increased revenues for management.

\section{Introduction}

Ecotourism, or nature tourism, is generally defined as travelling to relatively undeveloped natural areas to enjoy the scenery and wildlife (Boo, 1990; Jacobson, 1994), and is implicitly assumed to have little or no impact on the environment. Theoretically, ecotourism fosters sustainable management of resources (Jacobson, 1994), and therefore appears to be an ideal solution for combining goals of development and conservation. In practice, however, there are some fundamental questions about whether ecotourism can help maintain biological wealth, while also promoting economic well-being (Farrell and Runyan, 1991; Weber, 1993). Tourism can have long-term negative effects on reserves and local communities if uncontrolled or improperly managed (Mathieson and Wall, 1982; Pleumarom, 1993; Norris, 1994).

The question of whether tourism affects wildlife is also of critical concern. Is the passive viewing of wildlife free from negative impacts? How frequently may animals be disturbed before they change their behaviour? What degree of behavioural change represents a threat to a species? In Kenyan parks, disturbance by tour buses seriously reduces capture rates by cheetah (Weber, 1993). Jacobson (1994) documented disruption of sea turtle nesting by tourists along beaches of Tortuguero National Park, Costa Rica. In Sumatra, van Schaik and Griffiths (1993) suggest tourism may cause species population changes.

In an attempt to integrate the goals of development and nature conservation, Indonesia, like many other developing countries, is turning to ecotourism (Carey, 1991; Ruschmann, 1992; Giannecchini, 1993; Weber, 1993). The Tangkoko DuaSudara Nature Reserve, North Sulawesi, provides an excellent example of an Indonesian protected area that is experiencing a dramatic growth in ecotourism. Although federal law (Nature Protection Ordinance of 1941) prohibits tourism in Indonesian nature reserves (Suwelo, 1994), it is promoted by provincial and district governments. The Nature Protection Ordinance states that any 
activity, such as tourism, which 'changes the character of the soil, flora or fauna in any way or affects its pristine condition' is prohibited in strict nature reserves. In part, because the goals of a nature reserve exclude tourism, this activity is not managed in Tangkoko and the potential for negative impacts as well as loss of revenues is great.

In this paper we present the results of an analysis of tourism in the Tangkoko DuaSudara Nature Reserve. We use a threestep approach by evaluating the tourist experience, the impacts on wildlife, and the distribution of revenues. Specifically, we surveyed tourists to assess motivation for visits, level of satisfaction, and expenditures. Because primates are the primary wildlife attraction, we monitored responses of Sulawesi crested black macaques Macaca nigra to tourists and potential impacts of tourists visiting spectral tarsier Tarsier spectrum sleeping trees. Finally, we estimated monetary profits accrued by the local communities.

\section{Study area and methods}

Our study was conducted in the Tangkoko DuaSudara Nature Reserve (hereafter referred to as Tangkoko), North Sulawesi, Indonesia (Figure 1). The reserve was established in 1919 by the Dutch colonial government and retained as a nature reserve by the newly independent Indonesian government in 1945. Tangkoko is a small reserve of approximately 8800 ha and is broadly classified as lowland rain forest (IUCN, 1991). The reserve contains a wide spectrum of Sulawesi bird and mammal fauna and boasts one of the highest numbers of endemics of any protected area in Sulawesi (MacKinnon and MacKinnon, 1980). An unusually high density of animals, particularly primates and hornbills (MacKinnon and MacKinnon, 1980; M. Kinnaird and T. O'Brien, unpubl. data) provides greater viewing opportunities than normally experienced in rain-forest habitats. Easy wildlife viewing, combined with the reserve's relative

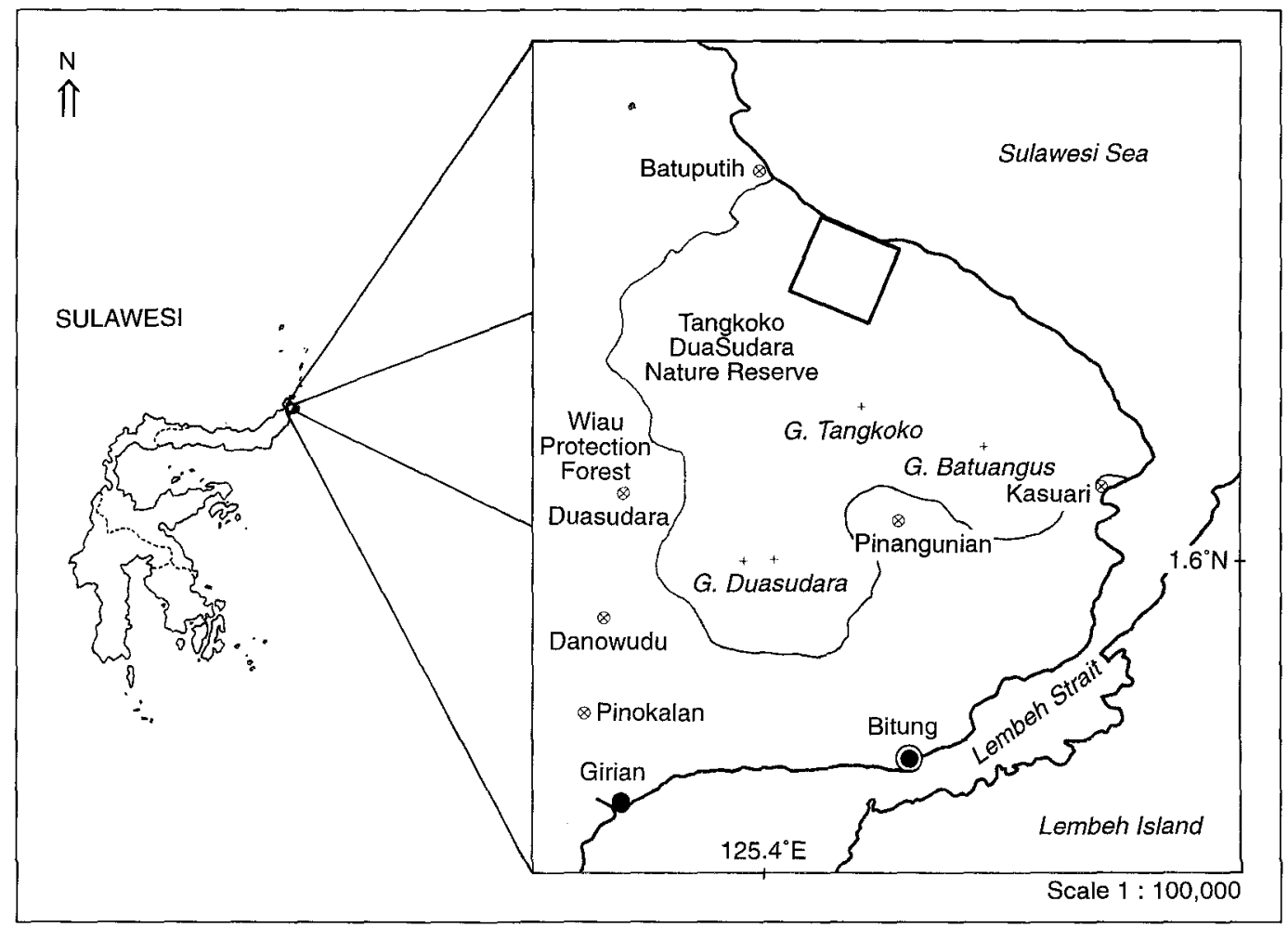

Figure 1. Map of the Tangkoko DuaSudara Nature Reserve and surrounding villages. Box denotes study area. 
accessibility ( $2.5 \mathrm{~h}$ by road from the provincial capital of Manado) make Tangkoko an attractive tourist destination. Although the reserve is ringed by villages, all tourist activity is concentrated in Batuputih village on the northeast boundary (Figure 1).

Monthly tourist statistics are available from 1990 onwards from registration books kept at the reserve entrance. We used these books to compile data on the number and nationality of tourists from 1990 to 1993. From July 1993 to December 1993, we distributed 200 questionnaires to tourists staying overnight in the adjacent village. In the questionnaire, we requested information regarding expectations for wildlife viewing, animals observed, length of stay, number and duration of trips into forest, quality of guiding, estimated amount of money spent, and highlights and disappointments of visit.

We monitored tourist activities and macaque response to tourist groups over 5 months (August 1993-December 1993) for three macaque groups. The three macaque groups comprised 49 (Malonda), 60 (Dua) and 97 (Rambo) individuals, groups 1-3, respectively. All groups were habituated to human presence (sensu Tutin and Fernandez, 1991) for 1 year before the start of this study. Each macaque group was followed by one or two observers from dawn to dusk, 6 days a week. During these sessions we recorded the number of tourists visiting monkey groups, the length of stay, general tourist behaviour and macaque response to tourist groups. We classified the dominant response of macaque groups according to degree of fear displayed: $\mathrm{run} / \mathrm{scream}$ being the most frightened state followed by retreating into the trees, group splitting and no response. Because black macaques are semiterrestrial and spend 60 per cent of the day on ground (Kinnaird and $\mathrm{O}^{\prime}$ Brien, unpubl. data) we considered a departure from the ground into the trees as a sign of disturbance.

We monitored tourist group size and behaviour while viewing tarsiers at one sleeping tree. Tarsier response to tourists, measured as departure time from the sleeping tree, was monitored opportunistically.

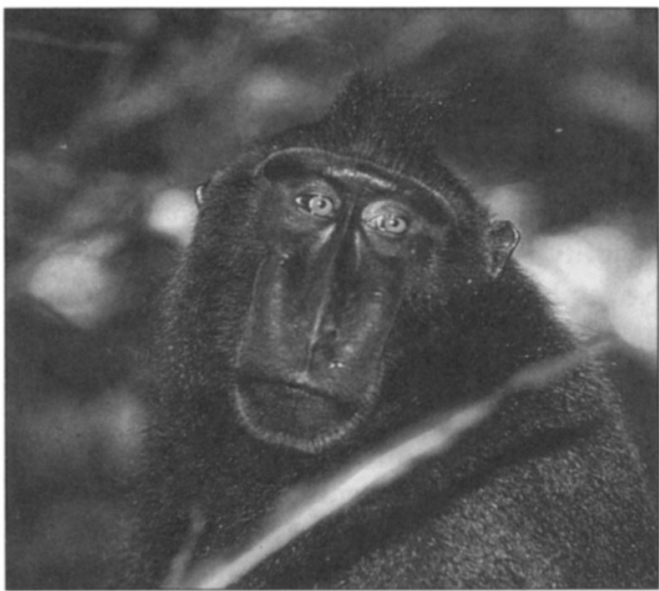

Crested black macaque (M. F. Kinnaird).

\section{Results}

Trends in tourism and response to questionnaire

Foreign tourism in Tangkoko became popular in the 1980s. MacKinnon and MacKinnon (1980) recorded only 50 foreigners visiting

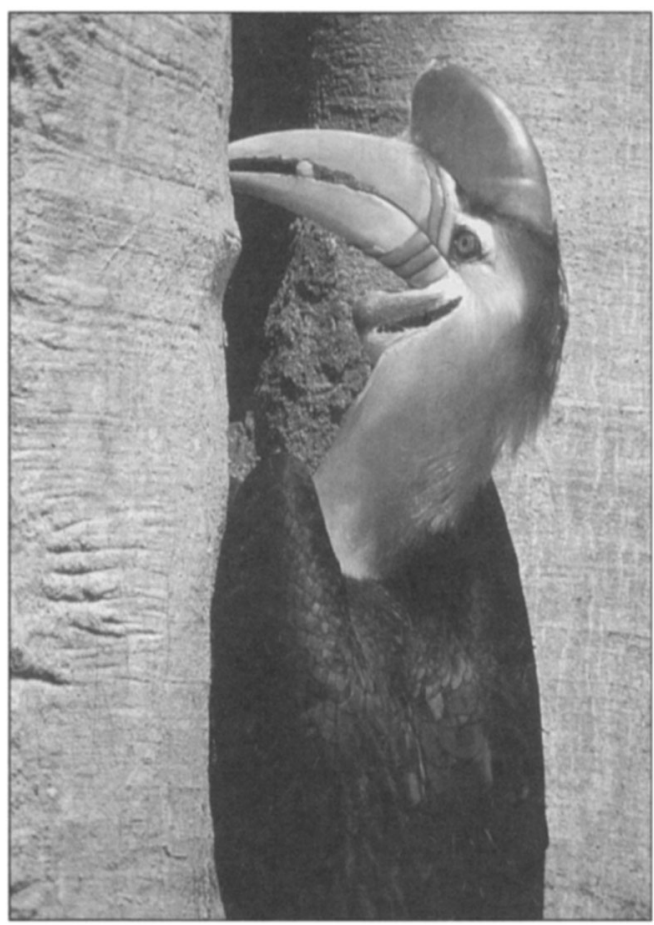

Red-knobbed hornbill Rhyticeros cassidix (M. F. Kinnaird), 
Tangkoko in 1978. By 1990, the number of foreign visitors had risen to 634 . Since 1990 , foreign tourism increased almost 250 per cent with 1515 visitors in 1993. Domestic tourism is relatively stable at around 3000 visitors per year (Figure 2). Tourism is seasonal with the majority of visitors arriving from July to November (Figure 3). The four most common nationalities of visitors are Dutch (23 per cent), German (21 per cent), American (14 per cent) and British (12 per cent).

Eighty-seven tourists responded to our questionnaire, representing a 44 per cent response. Of the respondents, 57 per cent came to see a particular animal. The first choices were the spectral tarsier and black macaque (74 per cent of those with a preference). Primate viewing, therefore, appears to be the most important feature attracting tourists. Tourists visit the reserve for an average of 2 days (range 1-3) and 1.8 nights (range 1-4). The average tourist enters the forest twice (range 1-5) and stays $3.8 \mathrm{~h}$ (range 1-8) per trip.

Wildlife viewing in rain-forest ecosystems is notoriously difficult but visitors to Tangkoko were extremely successful at seeing wildlife. Thirty-four per cent of respondents saw all of the Tangkoko 'big five' (spectral tarsier, black macaque, red-knobbed hornbill Rhyticeros

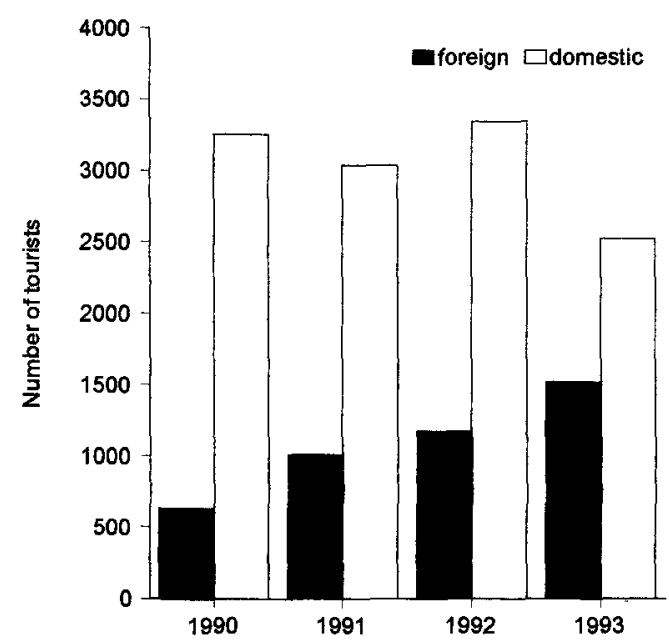

Figure 2. Trends in numbers of foreign and domestic tourists visiting Tangkoko from 1990 to 1993. cassidix, bear cuscus Ailurops ursinus and one of five endemic kingfishers), and all but 3 per cent of the visitors saw at least two of these species. Of those tourists staying a minimum of 2 days, nearly all were able to observe macaques, tarsiers and hornbills (94, 87 and 95 per cent, respectively) and over half saw cuscus and an endemic kingfisher (65 and 66 per cent, respectively).

Although guides are not required, 94 per cent of all foreign tourists take a guide when entering the forest. Guides were rated on a scale of $0-5$ ( 5 is the top score) by tourists for language skills and knowledge of the forest. The mean score for forest knowledge (4.3) was higher than the mean language score (3.1), indicating that tourists feel guides have more to offer but cannot adequately convey their knowledge. Guiding is carried out primarily by reserve guards; local villagers are allowed to guide rarely and only when no guards are available.

Irrespective of whether their initial expectations were met, visitors' experiences generally were favourable. Forty-nine per cent of the respondents listed attributes of the forest (big trees, ambiance, fresh air, etc.) as the highlight of their visit; an additional 29 per cent listed viewing a particular animal species as the highlight. Although 57 per cent stated that they came to view a particular animal, the highlight of their trip was not necessarily the fulfilment of this wish; some were more impressed with the forest environment. Disappointments focused on lack of proper reserve management. Of 63 responses, 24 per cent cited uncontrolled hunting, forest fires, litter and lack of tourist management as disappointments. An additional 23 per cent listed lack of information and poor guiding as disappointments. For example, tourist brochures for Tangkoko state that it is possible to see babirusa Babyrousa babyrussa, anoa Buzbalus depressicornis and maleo birds Macrocephalon maleo, animals that are either extinct (babirusa) or extremely rare within the reserve ( $T$. $\mathrm{O}^{\prime}$ Brien and M. Kinnaird, unpubl. data). Large, noisy tourist groups and wildlife harassment by guides also were mentioned. 
Figure 3. Average numbers of tourists visiting Tangkoko by month.

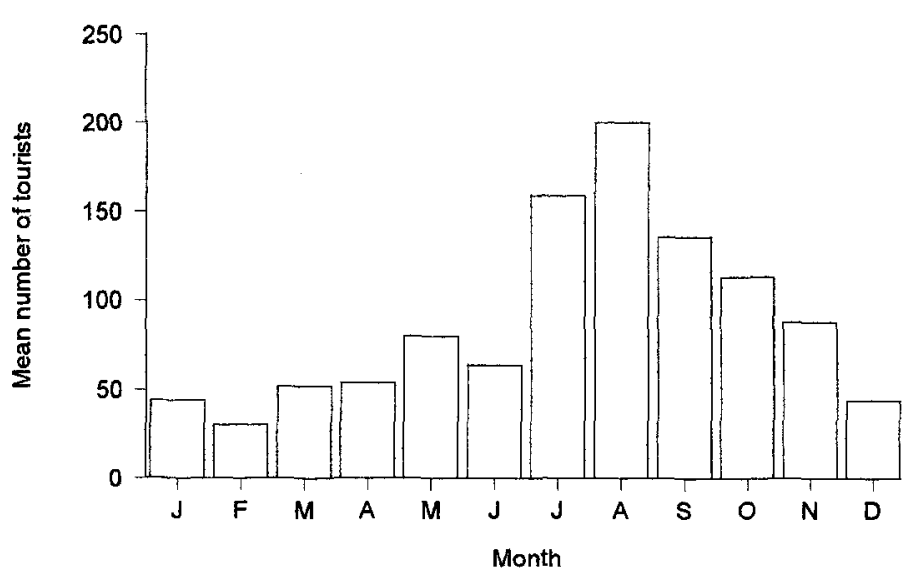

\section{Wildlife response}

Crested black macaque. One-hundred-and-fiftyone tourist groups were observed interacting with macaques. Tourist group size, for all primate groups combined, had a significant effect on primate response $\left(\chi^{2}=43.96\right.$, d.f. $=6, P<$ $0.0001)$. The greatest contributions to the overall chi-squared statistic were due to a lower than expected number of responses in a combined 'group split' and 'exit to trees' response category for tourist groups of two-three individuals, and a greater than expected number of responses in the same category for tourist groups of seven or more individuals. A lower than expected number of 'calm' responses with tourists groups of seven or more and a greater than expected number of 'run/scream' responses to tourists groups of six-seven individuals also contributed to the chi-squared statistic.

Macaque response to tourists varied among macaque groups. Group 3, the largest group, which receives 60 per cent of tourist visits, tolerated groups of up to seven individuals (Figure 4). As tourist groups exceed seven, group 3 tended to split into subgroups, often with females moving away from tourist groups as adult and subadult males guard. Lactating females in particular showed the most fear of tourist groups.

Group 1, the smallest group, showed a complete lack of tolerance for groups of greater than seven people and always retreated into the trees (Figure 4). The percentage of 'calm'
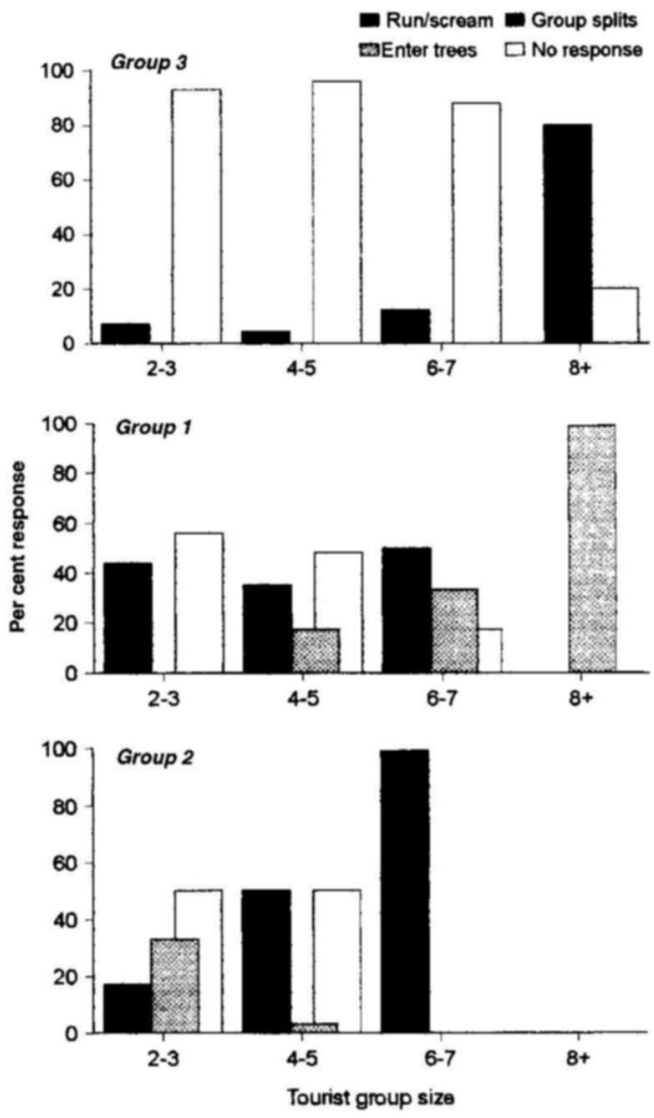

Figure 4. Response of three macaque groups to varying tourist group size. 
responses to tourists by the monkeys decreased with increasing tourist group size, indicating increasing levels of disturbance with larger tourist groups. Group 2 showed an even lower level of tolerance than group 1 and always fled from groups of greater than five tourists (Figure 4).

Negative response could sometimes be tempered by tourist behaviour. If tourists entered groups quietly and stooped down, letting the monkeys approach, the response was less fearful. Fleeing responses to party sizes of four-five were observed when tourists talked loudly and pursued monkeys off trails.

These data suggest that the optimum visitor group size should be four-five individuals. Although groups of seven tourists may be tolerated by the largest macaque group, the optimum tourist group size should be that which can encounter any of the habituated groups without causing a 'flee' response. Fortunately, the mean group size observed was 4.3 , including guide. Almost 40 per cent of the groups however, are above this optimum and we have recorded tourist groups as large as 17 visiting the macaques.

Spectral tarsier. Tarsiers are viewed primarily at two sleeping sites. Viewing typically occurs at dusk as the tarsiers emerge from their nests. Because viewing is restricted in time and space, crowds of up to 30 people gather to view tarsiers. We did not measure response quantitatively, but our observations suggested that large tourist groups result in delayed departure from sleeping trees, particularly when

Table 1. Distribution of tourist revenues in the Tangkoko DuaSudara Nature Reserve, 1993

\begin{tabular}{llc}
\hline & \multicolumn{2}{l}{ Current revenues } \\
\cline { 2 - 3 } Source & $\begin{array}{l}\text { Estimate } \\
(\$ U S)\end{array}$ & $\begin{array}{l}\text { \% total } \\
\text { earnings }\end{array}$ \\
\hline Manado Tour Co. & $24,882.00$ & 47 \\
Losmen & $23,110.00$ & 44 \\
Guides & $3,455.00$ & 7 \\
Entrance fees & $1,258.00$ & 2 \\
Total & $48,621.00$ & 100 \\
\hline
\end{tabular}

the tree is surrounded by large numbers of tourists with flashlights and flash cameras. Use of strong, electronic flashes for photography at distances of less than $2 \mathrm{~m}$ appeared to momentarily stun animals.

Tarsiers temporarily abandoned one sleeping tree (used for more than 4 years) after several nights of visits by tourist groups larger than 20. Guides have been observed grabbing tarsiers on several occasions and tourists have been observed climbing sleeping trees and shaking understorey perches.

\section{Tourist revenues}

We estimated 1993 revenues to several groups based on current gate fees, tour and guide fees, hotel (losmen) prices and estimates given by tourists in response to our questionnaire (Table 1). The majority of the tourist revenue stays in the provincial capital of Manado. Approximately 30 per cent of tourists used Manado travel companies. These companies secured on average $\$$ US50/person (range \$US40-75) for a 1-day trip to Tangkoko. Because tourists stay overnight in Manado, and bring their own food and guide, the local community does not profit from this tourism.

The losman owners secure the next largest percentage of revenues from Tangkoko. Three losmen are available to tourists in Batuputih; all are owned by reserve guards. Guides receive Rp10,000 (\$US5.00) from a tourist group for each walk. Each guide pays the head guard 20 per cent of his earnings.

The reserve receives 2 per cent of the total profits. Each tourist pays Rp750 (\$US0.35) to enter the park and most of this money is paid to the North Sulawesi Government.

\section{Discussion}

According to the World Tourist Organization, tourists travelling to developing countries, including Indonesia, are expected to reach 937 million by the year 2010, almost doubling the 500 million registered in 1993 (Pleumarom, 1993). By 1996, tourism receipts are expected to yield \$US3 trillion, making travel and 
tourism the largest single industry in the world, with nature tourism the strongest growing sector in the industry overall (Giannecchini, 1993). Tourism in North Sulawesi is exceeding world trends; foreign tourism is increasing annually at 30 per cent (NRMP, 1993). Due primarily to world-class diving (Muller, 1992) available in the newly established Bunaken National Marine Park and excellent wildlife viewing in nearby Tangkoko, tourism is expected to expand at this rate until the end of the decade (NRMP, 1993). To regulate this burgeoning growth, there is urgent need for a master plan for ecotourism development. Such plans are under way already for Bunaken National Marine Park; Tangkoko is more problematic because tourism is technically illegal and therefore the government cannot develop or implement tourism management plans. The present situation, however, requires attention to correct negative trends. Our data suggest that primate behaviour is being affected, local benefits are not being fully realized and the reserve does not generate enough money to implement management. Unfortunately, this situation is not unique to Tangkoko.

Ecotourism is a powerful marketing device and has succeeded in generating travel industries for many developing countries (e.g. Costa Rica and Ecuador: Norris, 1994). Local communities, however, seldom benefit because they are generally excluded from management and have little control over profits (Drake, 1991; IBR et al., 1992). For example, in Nepal's Annapurna region, where local communities provide accommodation for trekkers, only 20 cents of the \$US3 average daily expenditure stays with villagers (Wells, 1993; Pleumarom, 1994). The community of Ubud, on the Indonesian island of Bali, may serve as one exception; local organizations have limited development by outsiders by enforcing strict regulations for tourism and promoting projects that benefit the community (Pleumarom, 1994). This 'bottom-up' approach is also being used to incorporate local communities in the development of the Bunaken National Marine Park management plan (G. Usher, pers. comm.).

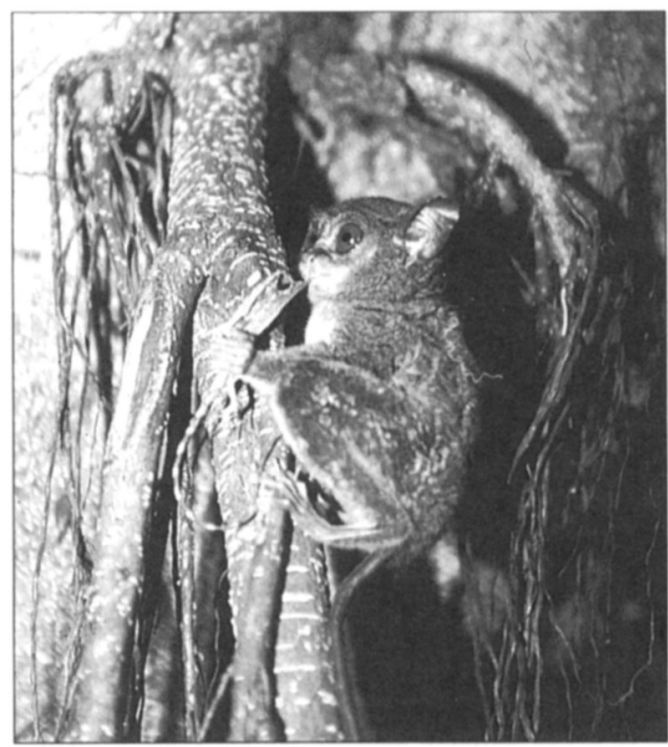

Spectral tarsier Tarsius spectrum (M. F. Kinnaird).

As is the case for most other protected areas, our data for Tangkoko showed that money generated by ecotourism does not necessarily go towards maintaining biological diversity (Wells, 1993). The Department of Forestry, which is responsible for reserve management, receives 2 per cent of the total income generated; only a fraction of this sum is allocated for Tangkoko. As a result there is little financial support for conservation activities in the reserve. For example, illegal hunting is a major problem but rangers have little incentive to patrol. It is far more profitable to guide tourists instead. The macaque population, upon which the foundation of tourism rests, consequently has declined by approximately 75 per cent over the last 15 years (O'Brien and Kinnaird, 1994).

Finally, the impact of tourists on wildlife cannot be ignored. Black macaques appear to be negatively affected by large groups of visitors. Repeated retreats into trees and subdivision of social groups disrupt daily activity patterns. As tourist pressure increases and visits by large groups are more frequent, time allotted by macaques for foraging and feeding could be seriously reduced. In addition, if unsupervised tourists were to start feeding macaques, activity budgets could change dramatically and interactions with tourists could 
become aggressive. Leary and $\mathrm{Fa}$ (1993) showed that barbary macaques Macaca sylvanus fed by tourists in Gibraltar altered daily activity patterns to adapt to tourist visits; interaction rates between tourists and macaques were as high as 99.6 interactions/hour. In the Sangeh Monkey Forest of Bali, Indonesia, long-tailed macaques Macaca fascicularis jump on tourists, bite, and steal objects to secure food items (Small, 1995). Chimpanzees Pan troglodytes in the Kibale Forest, Uganda, however, showed little behavioural response other than increased rate of vocalization to increasing tourist group size (B. Johns, pers. comm.).

The effect of tourism on tarsiers, especially the impact of flash photography on night vision, requires further investigation. Our qualitative observations, however, suggest that large tourist groups delay tarsiers from leaving sleeping sites and may significantly reduce early evening foraging opportunities.

The current status of Tangkoko as a nature reserve precludes tourist management even as the number of tourists increases yearly. Because Indonesian national parks include nature tourism as a management objective, it is appropriate that the status of Tangkoko be changed to that of a national park. The new status would accommodate ecotourism planning and management, could provide for greater participation by the local community, and could secure increased revenues for management. Possible constraints to these recommendations include the small size of Tangkoko; most Indonesian National Parks are greater than 20,000 ha. This impediment could be overcome, however, by creating Tangkoko as a sister park to the larger, nearby Bunaken Marine National Park. The concept of sister parks is not new to Indonesia. The small, volcanic island of Krakatau has been gazetted as part of Ujung Kulon National Park, a larger protected area on the western tip of nearby Java.

Many governments capture a share of the economic value of nature tourism by charging entry fees to visitors (Wells, 1993). Some areas are so popular that they can charge relative high prices. Tourists pay \$US60 to enter Galápagos National Park, Ecuador, and up to
\$US170 to visit mountain gorillas in Parc National des Volcans, Rwanda. Indonesia tends to charge very little for entrance to protected areas; tourists pay only Rp1000 (\$US0.50) for entrance to Komodo National Park to view Komodo dragons Varanus komodoensis and Rp5000 (\$US2.50) for entrance to Gunung Leuser National Park, Sumatra, a popular trekking destination. An entrance fee of $\$$ US10.00/foreign tourist would increase Tangkoko revenues 14-fold, from 1993 values of $\$ U S 1250$ to $\$ U S 17,600$. Although greater revenues do not guarantee increased protection, they do increase available options. The Mountain Gorilla Project (MGP) in Rwanda serves as an exceptional and valuable model of an ecotourism program that resulted in increased species protection. Through conservation education and a highly controlled tourism programme based on viewing gorillas coupled with adequate entrance fees that support improved park security, the MGP has had a very positive influence on the conservation and protection of the endangered mountain gorilla (Weber, 1993).

Currently 'ecotourists' control Tangkoko, probably to the detriment of wildlife. There is an urgent need for high-quality, supervised guiding. Tourists should be restricted to designated trails and travel in small groups (maximum of five, including guide) to minimize their impact. Tourists also desire information about forest ecosystems and guides should be trained to provide that information. Training and licensing local guides would help provide a high standard of service that would command higher guide fees, thereby improving benefits to the community. A high standard of guiding should also decrease negative impacts of tourists on wildlife (NRMP, 1993).

As more information is collected, it is clear that ecotourism is not a panacea for maintaining biodiversity. There is no ecologically neutral tourism; there will always be impacts. Our challenge, now that we have opened Pandora's box, is to minimize these impacts by developing and implementing wise touristmanagement plans. 


\section{Acknowledgements}

This work was funded by the Wildlife Conservation Society, the National Geographic Society and the Wenner-Gren Foundation for Anthropological Research. Puslitbang Biologi of the Indonesian Institute of Sciences (LIPI) and the Directorate General for Nature Preservation and Forest Protection (PHPA) sponsored our research in Indonesia. Special acknowledgements go to Romon Palete, Sub-Balai PHPA North Sulawesi, for his comments and encouragement. We thank losmen owners, Roos Masedung and Eta Sabanari for assisting with the tourist survey. We especially thank our monkey trackers, Felix Manderos, Uria Ganta, Celcius Campungbae, Saskar Tinungki, Simson Katiandagho and Herman Luas, for their long hours in the field.

\section{References}

Boo, E. 1990. Ecotourism: the Potentials and Pitfalls. Vol. 1. World Wildlife Fund Publication, Baltimore, USA.

Carey, S. 1991. Tourist spots developing 'green' images. Wall Street Journal, 10 May.

Drake, S.P. 1991. Ecotourism, and its role in sustainable development. In Nature Tourism: Managing for the Environment (ed. T. Whelan), pp. 132-163. Island Press, Washington, DC.

Farrell, B.H. and Runyan, D. 1991. Ecology and tourism. Ann. Tourism Res. 18, 26-40.

Giannecchini, J. 1993. Ecotourism: New partners, new relationships. Conservation Biology, 7, 429-432.

IBR/World Bank/WWF/USAID. 1992. People and Parks: Linking Protected Area Management with Local Communities. Washington, DC.

IUCN. 1991. Atlas of Tropical Rainforests. IUCN, Gland, Switzerland.

Jacobson, S.K. 1994. Biological impacts of ecotourism: tourists and nesting turtles in Tortuguero National Park, Costa Rica. Wildlife Society Bulletin, 22, 414-419.

Leary, H.O. and Fa J.E. 1993. Effects of tourists on Barbary macaques at Gibraltar. Folia Primatologica, 61, 77-91.

MacKinnon, J and MacKinnon, K. 1980. Cagar Alam Gn. Tangkoko-Dua Saudara, Sulawesi Utara
Management Plan, 1981-1986. WWF Report, Bogor.

Mathieson, A and Wall, G. 1982. Tourism: Economic, Physical and Social Impacts. Longman Group Ltd, Essex, UK.

Muller K. 1992. Underwater Indonesia. A Guide to the World's Greatest Diving. Periplus Editions, Singapore.

Norris, R. 1994. Ecotourism in the National Parks of Latin America. National Parks, January/February.

NRMP (Natural Resources Management Project). 1993. Ecotourism development in Bunaken National Park and North Sulawesi. Report No. 30 to Associates in Rural Development for Office of Agro-Enterprise and Environment, AID Contract No. 497-0362.

O'Brien, T.G. and Kinnaird, M.F. 1994. Population declines of large birds and mammals in North Sulawesi. Proceedings of the First Conference on Eastern Indo-Australian Vertebrates. Manado, Indonesia. Abstract.

Pleumarom, A. 1993. The political economy of tourism. The Ecologist, 24, 142-147.

Ruschmann, D.V. 1992. Ecological tourism in Brazil. Tourism Management, 13, 125-128.

van Schaik, C.P. and Griffiths, M. 1993. The impact of human traffic on the abundance and activity periods of Sumatran rain forest wildlife. Conservation Biology, 7, 623-626.

Small, M. 1995. Hanuman's troops, servants of the gods. Garuda Air Magazine, January, 26-28.

Suwelo, I.S. 1994. Indonesia's conservation policy. TigerPaper, 21 (2), 23-25.

Tutin, C.E.G. and Fernandez, M. 1991. Responses of wild chimpanzees and gorillas to the arrival of primatologists: behaviour observed during habituation. In Primate Response to Environmental Change (ed. H. O. Box), pp. 187-197. Chapman \& Hall, New York.

Weber, W. 1993. Primate conservation and ecotourism in Africa. In The Conservation of Genetic Resources (ed. C. Potter), pp. 129-150. American Association for the Advancement of Science, USA. Wells, M.P. 1993. Neglect of biological riches: the economics of nature tourism in Nepal. Biodiversity and Conservation, 2, 445-464.

Margaret F. Kinnaird and Timothy G. O'Brien, Wildlife Conservation Society, 185th and Southern Blvd, Bronx, NY 10460, USA 